\title{
DEVELOPMENT AND PERFORMANCE OF THE PUBLIC REAL ESTATE INVESTMENT SECTOR IN FINLAND
}

\author{
Heidi FALKENBACH ${ }^{1}$, Jaakko NISKANEN ${ }^{2}$ and Sami KIEHELÄ 3 \\ ${ }^{1}$ Real Estate Research Group, School of Engineering, Aalto University, P. O. Box 15800, Aalto \\ FI-00076, Finland \\ E-mail: heidi.falkenbach@aalto.fi \\ ${ }^{2}$ Real Estate Research Group, School of Engineering, Aalto University, P. O. Box 15800, Aalto \\ FI-00076, Finland \\ E-mail: jaakko.niskanen@aalto.fi \\ ${ }^{3}$ Real Estate Research Group, School of Engineering, Aalto University, P. O. Box 15800, Aalto \\ FI-00076, Finland \\ E-mail: sami.kiehela@aalto.fi
}

Received 17 February 2012; accepted 27 June 2012

\begin{abstract}
The article studies the development of the public real estate equity sector. The paper describes and analyses the legislative development regarding the sector and the vehicles provided. It discusses the past development of public commercial real estate equity investments in Finland and their role as a market participant. In addition, the paper analyses the historical performance of the sector.
\end{abstract}

KEYWORDS: Real estate investment; Indirect investments; Real estate operating company; Real estate stocks; Finland

REFERENCE to this paper should be made as follows: Falkenbach, H., Niskanen, J. and Kiehelä, S. (2013) Development and performance of the public real estate investment sector in Finland, International Journal of Strategic Property Management, 17(3), pp. 233-247.

\section{INTRODUCTION}

The role of real estate investments as a diversifier of a mixed asset portfolio has been discussed thoroughly in the academic literature. Seiler et al. (1999) provide a review of the early studies summarising that property has a low correlation with other asset classes and thus should have a place in a mixed asset portfolio. The early literature was focused on the U.S. and U.K. market, and more recent literature confirms that diversification benefits are also available in the other European markets (see e.g. Stevenson, 2000; Fraser et al., 2002; Hoesli et al., 2004) and in Finnish markets (Falkenbach, 2009a).
Due to the characteristics of real estate, the inclusion of real estate in a portfolio poses challenges to the investor: For example, the unit size of the investment is large and the properties heterogeneous, which makes constructing a diversified real estate portfolio difficult. In addition, real estate investments require ongoing management as well as assetand market-specific knowledge.

Some of these challenges can be avoided by investing in real estate through indirect means. The variety of instruments can be illustrated by a four-quadrant model consisting of two dimensions: equity/debt and private/ public (see e.g. Hudson-Wilson et al., 2003). 
On the equity side, the investor gains exposure to the return on equity of real estate assets, whereas on the debt side, the return is tied to the pricing of risk (Hoesli and Lekander, 2008). Of these, this paper focuses on the equity instruments. The private real estate equity investments include direct real estate, as well as investment in private commingled vehicles, such as non-listed real estate funds. The public real estate equity investments, on which this paper concentrates, include investments in shares in publicly listed real estate investment trusts (REITs) and real estate operating companies (REOCs).

The public equity vehicles provide the investor with a standardised market place, high liquidity, and transparency. The unit size of investment is also markedly lower, and the investment does not require specific skills in real estate. Whereas the ease of investing in public vehicles makes them an attractive alternative to direct investments, the other side to the coin is also the investment returns differing from those of a direct investment. There is evidence in the literature of public real estate equities that the risk and return characteristics of these instruments are similar to those of stocks (see e.g. Eichholtz, 1996a, 1997; Ling and Naranjo, 1999; Fraser et al., 2002; Schulte et al., 2011). The partial independence of public real estate equity from direct real estate and stocks has sometimes even been interpreted to indicate that public real estate equity should be regarded as an asset class in itself, rather than as a substitute for direct investments, and deserves a place in a mixed-asset portfolio (e.g. Mueller G. A. and Mueller, R. G., 2009). On the other hand, there is also empirical evidence that the direct and public real estate returns are cointegrated, suggesting that in the long run direct and public real estate investments can be regarded as substitutes in a mixed asset portfolio (Pagliari et al., 2005; Oikarinen et al., 2011).

The public real estate equity market also has a role in the market maturity development process and especially in internationalisation of the property market. Indeed, studies on the barriers limiting the international activities of property investors emphasise problems related to the informational inefficiencies and management intensiveness of the investments (see Worzala, 1994; Newell and Worzala, 1995; McAllister, 1999). The questionnaire studies among institutional investors of Worzala (1994) and Newell and Worzala (1995) identify publicly traded shares as a lucrative form of conducting international real estate investments. This is further reflected in the studies on market selection criteria, where in a survey of international real estate investors, Falkenbach (2009b) found that the existence of indirect investment possibilities was regarded as a threshold condition for investing in a foreign real estate market by one-third of the respondents. In addition, the existence of these instruments affects the attractiveness of the market (Falkenbach, 2009b). She interprets this to be an indication that, in addition to serving as an important tool for those investors investing abroad through indirect means, some investors regard the existence of indirect vehicles as an indication of market maturity and liquidity.

The aim of this paper is to analyse the development and performance of the public real estate investment sector in Finland. In considering the role of public real estate operating companies in Finnish markets, three main issues were studied. Firstly, the regulation concerning the operation and taxation of the Finnish public vehicles is reviewed. Secondly, the development of the sector in terms of companies and the assets under management is conducted based on annual reports and financial statements $^{1}$ of the Finnish real estate operat-

\footnotetext{
1 The collection of data caused some hardship, as the quality of materials has varied significantly under the reference period. The significant issues to take into account when estimating the data quality are the following: Firstly, for clarity reasons, all figures in finnmarks have been converted into euros using the official conversation rate 1 euro $=5.94573$ FIM. Secondly, the annual reports of companies still existing in the markets were fairly easy to obtain. However, the annual reports for companies that were delisted during the turn of 80 's and 90's were not available for the researchers. The data was complemented with financial statements and balance sheets stored in the archives Finnish National Board of Patents and Registration of Trademarks.
} 
ing companies traded in the stock exchange's (OMX Helsinki, formerly HEX) main list or the OTC list. Thirdly, the vehicles are evaluated as investment assets by focusing on three viewpoints, i.e., net asset value discounts, liquidity of shares, and performance of the sector.

\section{BACKGROUND}

\subsection{Regulation of Finnish public real estate equities}

Finnish legislation acknowledges two types of public vehicles investing in real estate: public real estate operating companies (PREOCs) and real estate investment trusts (Finn REIT). Finnish public real estate operating companies are regulated according to the same laws as other public limited liability companies. All limited liability companies are regulated by the Finnish Companies Act (734/1978), and additionally, publicly traded companies have to comply with the Securities Market Act (495/1989). In addition, the Accounting Act (1336/1997) and Accounting Ordinance (1339/1997) affect the operations of PREOCs, especially the distribution of dividends. As with U.S. real estate operating companies (Delcoure and Dickens, 2004), Finnish PREOCs have no minimum requirements on dividend payouts, ownership, or portfolio structure.

Public real estate operating companies are subject to the corporate tax of $26 \%$ on profits generated by the company. In addition, shareholders are also liable to pay tax for income received in the form of dividends. Thereby, investments are subject to double taxation.

The law on Finn REITs (REIT Act, $1173 / 1997)$ is similar to those in the rest of the Europe (see Niskanen and Falkenbach, 2010), in that it imposes restrictions on permitted asset types, amount of development activities, maximum leverage, and valuation practises. However, in general it does not provide for tax transparency as with the corresponding vehicles in the U.S. and in Europe. Thus, Finn REITs in general are subject to stricter regulations than real estate operating companies operating in a limited liability company structure, but they receive no tax benefits.
The legislation on Finn REITs has been subject to a number of amendments since its inception in 1997, the latest change occurring in 2009. According to the latest amendment of the law in 2009, tax transparency can be provided for a Finn REIT investing in apartments (min. 80\% of assets), receiving a minimum of $80 \%$ of its income from rents of apartments, holding the investments for a minimum of 5 years and dividing $90 \%$ of its profits as dividends to shareholders. In addition, a REIT must be listed within 3 years of its inception date, and assets brought into the REIT structure from other operations will be taxed as if they were sold on the market. So far the amendment has not resulted in establishments of listed Finn REITs, but the first REIT has started its operations as a private company. Thus, public real estate operating companies remain the only form of public real estate investment in Finland.

\subsection{History of the vehicle}

The first real estate operating companies were listed in the Helsinki Stock Exchange (HEX) main list in 1988. At that time the Finnish real estate market was booming: financial markets had just been liberalized and the economy in general was already overheated. A common belief among investors was that property values could only increase and that real estate provided a total hedge agains inflation (Huoneistokeskus, 1992, p. 2). The economic growth in the services sector increased the demand for commercial premises, leading to increasing rents and soaring property prices (Karakozova, 2005, p. 4). During the boom years of 1988-1989, altogether 13 real estate operating companies went public, the estimated gross asset value of their holdings being about $€ 1.5$ billion. Table 1 illustrates the public real estate operating companies in the Finnish market, their listings, and eventual delistings. After the first few years, the sector witnessed restructuring through mergers and acquisitions, decreasing the number of listed companies to 10 by the end of 1990 . 
Table 1. PREOCs in the Finnish market

\begin{tabular}{|c|c|c|c|}
\hline REOC & Listing (HEX/OMX) & Delisting & Comments \\
\hline Citycon Plc & 1988 & & \\
\hline Julius Tallberg Kiinteistöt Plc & 1988 & 2010 & Delisted \\
\hline YIT-kiinteistöt Plc & 1988 & 1993 & Delisted \\
\hline Siltasaari-Invest Plc & 1988 & 1990 & Merged into Ferenda Plc \\
\hline Jämerä-Kiinteistöt Plc & 1988 & 1990 & Merged into Ferenda Plc \\
\hline Suomen Pörssikiinteistöt Plc & 1988 & 1990 & Merged into Ferenda Plc \\
\hline Finanssiosakeyhtiö Sensor Plc & 1988 & 1990 & $\begin{array}{l}\text { Withdrawn from stock exchange due to } \\
\text { unprofitability }\end{array}$ \\
\hline Suomen Kiinteistöinvestointi Plc & 1988 & 1993 & Bankrupt \\
\hline Castrum Plc & 1988 & 2001 & Delisted and merged to Sponda \\
\hline Turun arvokiinteistöt Plc & 1988 & 2005 & \\
\hline Interavanti Plc & 1988 & & \\
\hline Polar Kiinteistöt Plc & 1989 & 2004 & \\
\hline Suomen Säästäjien kiinteistöt Plc & 1989 & & \\
\hline Ferenda Plc & 1990 & 1991 & Bought by Polar Kiinteistöt \\
\hline Sponda Plc & 1998 & & \\
\hline Technolopolis Plc & 1999 & & \\
\hline
\end{tabular}

In 1991, the Finnish economy fell into a deep recession, which later deepened into a severe banking crisis. With the oversupply of commercial space generated during the property boom, the recession led to a sharp drop in property values, rents, and construction activity (Karakozova, 2005, p. 4). The severity of the recession and its effect on asset values and the wealth of listed companies can be seen in Figure 1. Gross asset values decreased to less than half of the pre-recession volumes by 1994. Of this decrease, only about $€ 100$ million stemmed from the asset values of the two companies leaving the stock exchange.

In the beginning of $1990 \mathrm{~s}$, property values had been high, and investments were also highly leveraged. The write-downs during the recession naturally weakened the net asset values of companies as asset values decreased and interest rates increased. Thereby, the debt-to-equity ratios increased from about $50 \%$ to more than $70 \%$ during the years 1992 to 1995 . Figure $1^{2}$ suggests that 1993 was the trough, as the sector's NAV fell to 200 million euros, i.e., to $30 \%$ of the net asset values prerecession. In 1993, the PREOC sector also experienced its first (and so far, the only) bankruptcy, as Suomen Kiinteistöinvestointi was officially declared bankrupt. In the same year, the majority owner of YIT-Kiinteistöt Plc, YIT Group, bought back all the shares of YIT Kiinteistöt Plc, and the company was delisted.

The Finnish economy and property markets started to recover in 1994. The general econo-

2 The authors faced some difficulty in defining the asset values of the companies: Before the introduction of IFRS-standards in 2005 Finnish PREOCs were not required to report the market values of their real estate holdings in their annual reports. Thus, the availability of the market values of property holdings varied from company to company. In cases where market value was not available, book value of properties is used. Book values are calculated based on the acquisition price less the depreciation. In addition, book values can be corrected for permanent changes in value through writeups and write-downs. 


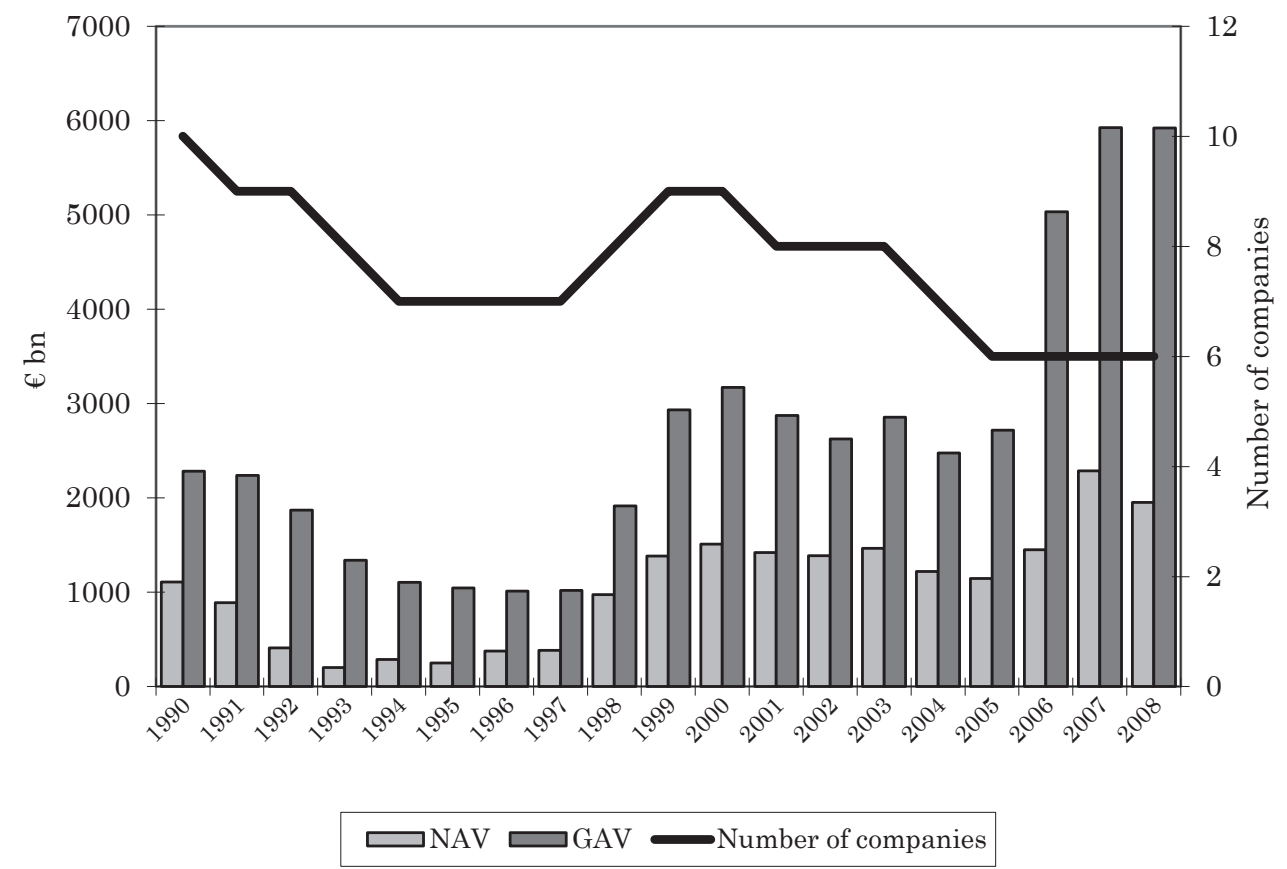

Figure 1. Gross and net asset values of public real estate operating companies 1990-2009

my entered a phase of steady growth, supported by joining the European Union in 1995. In the real estate markets, vacancies decreased, rent started to increase, and profits recovered. For the PREOCs, the early recovery offered no large changes. The values of the portfolios remained stable, and the wealth of the sector slowly improved.

The year 1998 showed the beginning of new growth in the sector, with a GAV jump of almost 1 million euros. More than half of this growth can be explained by the listing of Sponda Plc, a real estate operating company owned by the state of Finland and Merita bank, whose real estate portfolio's GAV was almost 600 million euro. Also the portfolio of Citycon grew markedly during the year. Shortly after that, in 1999, Technolopolis Plc, a real estate operating company focusing on technology centres, also entered the stock exchange. The sector experienced its peak in 2000, exceeding a GAV of more than 3 billion. A second peak occurred in 2006, as Sponda Plc purchased the state-owned private real estate operating company Kapiteeli Ltd. The total value of the transaction was 943 million euros, and the estimated value of the property portfolio was 1.3 billion euros.

During 2003 and 2004, all the shares of Polar Plc were purchased by the German IVG consortium, and the company was delisted. The latest changes in the PREOC sector occurred as Turun Arvokiinteistöt Plc ended in financial distress and was delisted in 2005, and Julius Tallberg Kiinteistöt announced its delisting to take place in March 2010. Currently there are five public real estate operating companies in the Finnish markets.

\section{FINNISH PREOCS AS INVESTMENTS}

\subsection{Asset allocation}

The public real estate operating companies in Finland are all concentrated in commercial real estate. Table 2 illustrates the portfolios of the companies currently listed on the stock exchange. As shown, three of the companies have a real estate portfolio of mixed property types, the two other being focused on particu- 
lar property types, that is, retail for Citycon Plc, and office for Technopolis Plc. The five currently listed real estate operating companies have property holdings of about $€ 5.5$ billion, of which about $€ 5$ billion were properties in Finland. The size of the companies, however, varies significantly, the smallest company owning only two assets with a total worth of 5 million euro, and the largest more than 200 assets with a total value of almost 3 billion euro.
The holdings of the Finnish listed real estate operating companies are focused in the Helsinki metropolitan area and the largest Finnish cities, as is the commercial real estate market in Finland in general. The only exception to this is Suomen Säästäjien Kiinteistöt Plc (later SSK), which only owns assets in Pori. Most of the companies have also extended their activities to eastern European countries, such as Russia and the Baltic countries.

Table 2. Portfolios of Finnish PREOCs

\begin{tabular}{|c|c|c|c|}
\hline Company & $\begin{array}{l}\text { Real estate portfolio } \\
\text { (MEUR) }\end{array}$ & $\begin{array}{l}\text { Number of } \\
\text { properties }\end{array}$ & Real estate portfolio composition by type and location \\
\hline Citycon Plc & $\begin{array}{l}2023 \text { (1480 MEUR in } \\
\text { Finland) }\end{array}$ & $\begin{array}{l}85(67 \text { in } \\
\text { Finland) }\end{array}$ & $\begin{array}{l}\text { Retail (100\%) } \\
\text { HMA (32\%), other Finland (33\%), Sweden (29\%), Baltic } \\
(6 \%)\end{array}$ \\
\hline Interavanti Plc & $\begin{array}{l}40 \text { (ca. } 12 \text { MEUR in } \\
\text { Finland) }\end{array}$ & 12 & $\begin{array}{l}\text { Industrial ( } 76 \%) \text {, office }(17 \%) \text {, retail }(7 \%) \\
\text { HMA ( } 22 \%) \text {, Tampere }(4 \%) \text {, other Finland }(8 \%) \text {, Estonia } \\
(39 \%) \text {, Hungary }(16 \%) \text {, Poland (11\%) }\end{array}$ \\
\hline Sponda Plc & 2937 & $\begin{array}{l}209(202 \text { in } \\
\text { Finland) }\end{array}$ & $\begin{array}{l}\text { Office }(43 \%) \text { retail }(14 \%) \text {, Logistics }(35 \%) \text {, other }(8 \%) \\
\text { HMA ( } 87 \%) \text {, Tampere }(3 \%) \text {, Turku }(1 \%) \text {, Oulu }(1 \%) \text {, } \\
\text { other Finland (5\%), Russia (3\%) }\end{array}$ \\
\hline $\begin{array}{l}\text { Suomen } \\
\text { Säästäjien } \\
\text { Kiinteistöt Plc }\end{array}$ & 5 & 2 & $\begin{array}{l}\text { Pori }(100 \%) \\
\text { One retail property, and one mixed-use premises (office, } \\
\text { hotel, and retail) }\end{array}$ \\
\hline $\begin{array}{l}\text { Technopolis } \\
\text { Plc }\end{array}$ & 594 & 20 & $\begin{array}{l}\text { Office }(100 \%) \\
\text { Oulu (38\%), HMA ( } 25 \%) \text {, Jyväskylä }(12 \%) \text {, Kuopio } \\
(12 \%) \text {, other Finland (11\%), Russia }(2 \%)\end{array}$ \\
\hline
\end{tabular}

Note: all figures are from year 2008.

Source: Annual reports and home pages of companies.

Table 3. Size of public real estate markets in selected European countries (EPRA, 2009)

\begin{tabular}{llll}
\hline Country & $\begin{array}{l}\text { Number of listed } \\
\text { companies }\end{array}$ & $\begin{array}{l}\text { Share of public RE market } \\
\text { of total RE market (\%) }\end{array}$ & $\begin{array}{l}\text { Share of public RE of total } \\
\text { stock market }\end{array}$ \\
\hline Austria & 13 & $5.27 \%$ & $9.65 \%$ \\
Belgium & 19 & $3.27 \%$ & $3.75 \%$ \\
Denmark & 5 & $1.58 \%$ & $1.46 \%$ \\
Finland & $\mathbf{5}$ & $\mathbf{3 . 0 4} \%$ & $\mathbf{2 . 2 0} \%$ \\
France & 62 & $5.62 \%$ & $4.65 \%$ \\
Germany & 41 & $1.18 \%$ & $1.65 \%$ \\
Italy & 8 & $0.69 \%$ & $1.28 \%$ \\
Netherlands & 12 & $3.56 \%$ & $5.75 \%$ \\
Norway & 6 & $1.96 \%$ & $2.08 \%$ \\
Sweden & 15 & $7.79 \%$ & $5.91 \%$ \\
UK & 124 & $4.33 \%$ & $3.20 \%$ \\
Total Europe & 366 & $2,93 \%$ & $2,98 \%$ \\
\hline
\end{tabular}


Table 4. Ownership of the Finnish PREOCs

\begin{tabular}{lllllll}
\hline Company & \multicolumn{6}{l}{ Ownership (\%) } \\
\cline { 2 - 6 } & Companies & $\begin{array}{l}\text { Finance and insurance } \\
\text { institutions }\end{array}$ & $\begin{array}{l}\text { Public } \\
\text { entities }\end{array}$ & $\begin{array}{l}\text { Finnish } \\
\text { households }\end{array}$ & $\begin{array}{l}\text { Non-Profit } \\
\text { organisations }\end{array}$ & $\begin{array}{l}\text { Foreign } \\
\text { owners* }\end{array}$ \\
\hline Citycon & 1 & $73^{* *}$ & 1 & 3 & 0 & 23 \\
Interavanti**** & 93 & 0 & 0 & 7 & 0 & 0 \\
Sponda & 47 & 1 & 36 & 11 & 1 & 0 \\
SSK & $57^{* * * *}$ & 0 & 0 & $43^{* * * *}$ & 0 & 0 \\
Technopolis & 5 & 46 & 30 & 12 & 5 & 2 \\
\hline
\end{tabular}

Situation 31.12.2008.

* Foreign ownership; ** Most of these institutions are foreign, the total amount of foreign ownership being 95.3\%; *** Management owns $93.8 \%$ of the shares; **** Management and the family related to it own at least $49 \%$ of the company through companies and $33 \%$ as households.

Though the portfolios held by PREOCs have grown substantially during the past five years, the relative significance of the PREOC holdings in the Finnish commercial real estate markets is still fairly small. The current size of the institutionally owned commercial real estate market is estimated to have a value of 36 billion euro (KTI, 2009), whereas the value of properties held by public real estate operating companies was about 5 billion euro. The listed sector thus owns $14 \%$ of the institutionally owned commercial real estate stock, which is comparable to the figure in the U.S. (NAREIT, 2009).

According to the estimates of European Public Real Estate Association (EPRA, 2009), the listed real estate market represents ca. 3\% of the total value of Finnish real estate, which is a figure slightly above the European average of $2,9 \%$. When compared to other mature European real estate markets, the Finnish market still lags behind in development in terms of share of public real estate of total market and share of public real estate of stock market, and also in number of companies (see Table 3). Of the mature European markets only Germany has a significantly lower level of public real estate, but this is probably due to the well-developed open-ended real estate funds-sector in the country (see e.g. Focke, 2006). In comparison to Nordic markets, the public real estate market still lags behind the Swedish market, but is larger than the markets in Denmark and Norway.

\subsection{Ownership of shares}

The Finnish PREOCs have varying ownership structures (Table 4). The small PREOCs, SSK and Interavanti, have management as major shareholders, whereas the three larger ones have more diversified ownership structures. The largest shareholder of Sponda Plc is the Finnish state, representing one-third of the shares. Citycon Plc is mainly owned by foreign investors, Gazit Globe Plc owning almost 40\% of the shares. The major owners of Technopolis Plc are Finnish institutional investors and Finnish municipalities.

Listed real estate investment has often been lauded for providing a level playground for those investors who otherwise would not be able to participate in the real estate market, such as private households (Campbell and Sirmans, 2002). Figure 2 illustrates the ownership structure of Finnish PREOCs in market values. The extensive ownership of management in Interavanti and SSK have been corrected in the group "Other" to better illustrate the actual division of shares. In the other companies, management owns less than $0.3 \%$ of the shares. The largest ownership groups for the listed company shares are finance and insurance institutions, and especially pension funds, public entities (such as the state and 


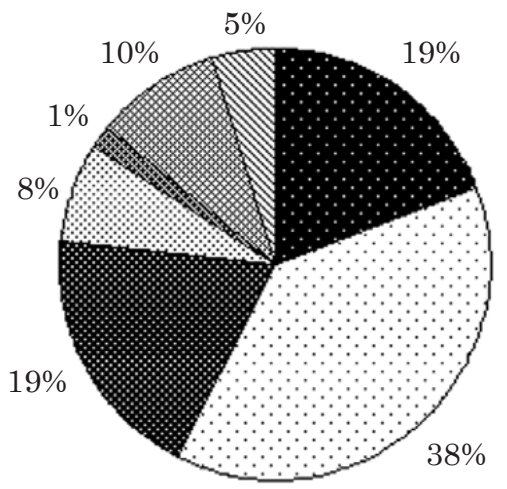

\begin{tabular}{|c|c|}
\hline - Companies & ․ Finance and insurance institutions \\
\hline . Public entities & 母 Households \\
\hline Non-Profit organisations & 国 Foreign owners \\
\hline $\mathbb{Q}$ Other & \\
\hline
\end{tabular}

Figure 2. Ownership of the Finnish REOCs by investor category

municipalities), and companies. Finnish private households own only $8 \%$ of the market, and foreign owners own $4 \%$. Thus, it can be concluded that the listed property investment companies have not channelled much funds of private households into the commercial real estate market, but remain rather an investment forum for the institutional owners. Similarly, even though public investments have been emphasised in the literature of international property investments, they have not played a major role in the internationalisation of the Finnish property market. It should, however, be noted that the foreign ownership which is organised through companies or finance and insurance institutions, is reported in the respective categories.

\subsection{Market value, pricing, and liquidity}

The market capitalisation of public real estate operating companies at the end of 2008 was almost 1 billion euro (Figure 3 ). The figure is currently fairly low, as the stock markets reacted aggressively to the global financial crisis in 2007-2008. As can be seen in the figure, the market values of PREOCs also plunged during the recession but have followed a fairly steady path since 1998.
Though the market capitalisation of public real estate operating companies has increased markedly during the past years, it still remains modest in relation to the market capitalisation of the OMX Helsinki Stock Exchange. In the beginning of 2009, PREOCs represented 2,2\% of the total stock market capitalisation (see Table 3), while the comparative figure for $\mathrm{Eu}$ rope is 3\% (EPRA, 2009).

As in other investment sectors, closed-ended funds - to which Finnish PREOCs can be classified into, too - typically trade at a discount value when compared to the value of the assets in their portfolio. In the public real estate markets, one would assume that due to differences in e.g. liquidity, trading, lot size and transaction costs between real estate assets and publicly traded real estate property, the public property companies would trade with a premium. A vast amount of general financial literature (see e.g. Pratt, 1966; Boudreaux, 1973; Malkiel, 1977) suggests the P/NAV discount to be a sign of irrational investors in the market who act based on market sentiment (noise traders) or a result of company specific factors. In public real estate markets these company specific factors could be, for example, amount of deferred taxes (Barkham and Ward, 1999), use of leverage (Barber, 1996; Clayton 


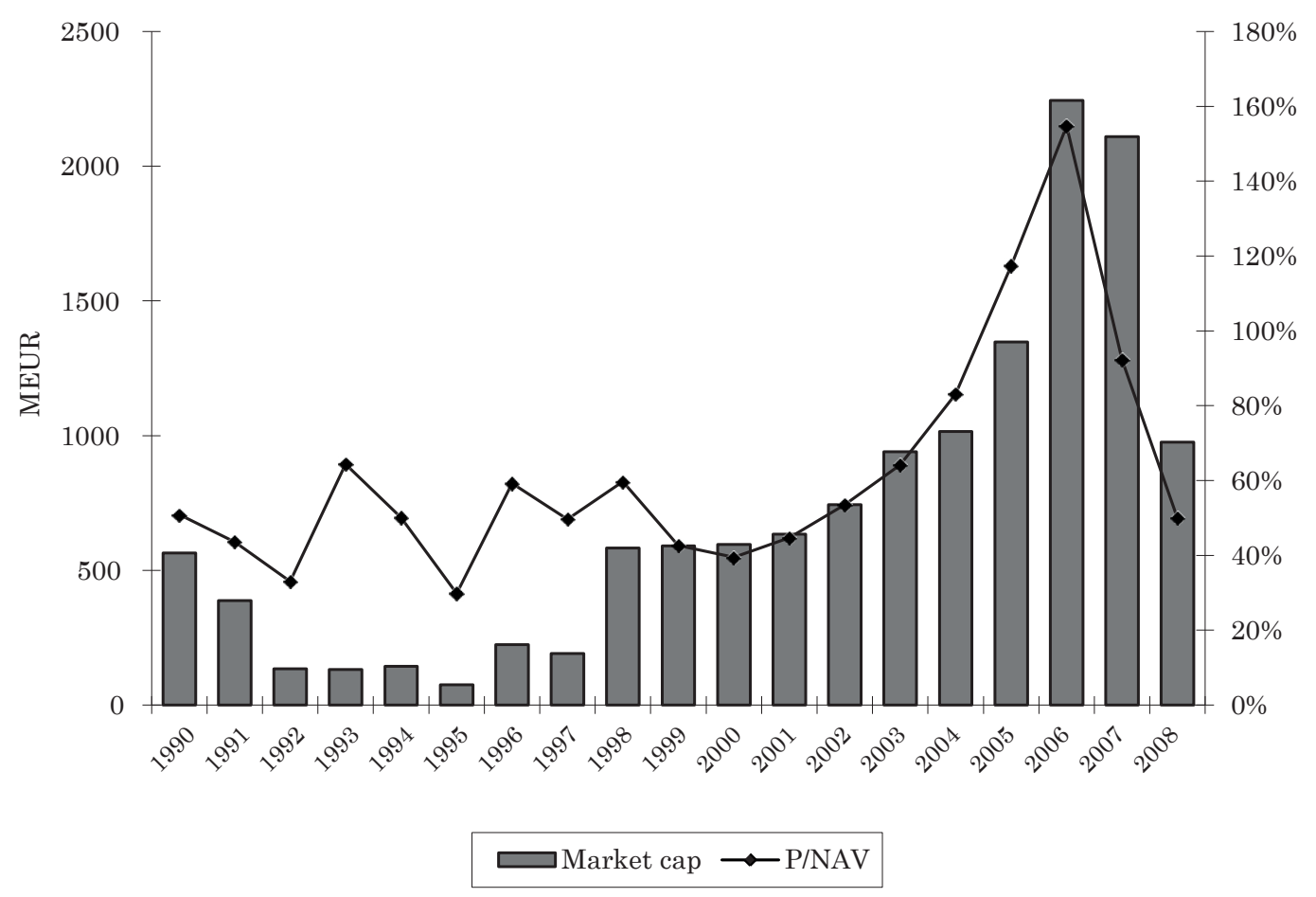

Figure 3. Market value and P/NAV ratio of PREOCs

and MacKinnon, 2001; Anderson et al., 2001; Morri et al., 2005), liquidity of shares (Clayton and MacKinnon, 2001; Brounen and ter Laak, 2005; Biasin et al., 2010) and size of company (Capozza and Lee, 1995; Clayton and MacKinnon, 2001).

For the 1990s, the P/NAV ratio of the Finnish PREOCs remained around 40\%, but showed much volatility. The Finnish property markets also experienced rapid growth in the beginning of the 21st century, and the excess demand experienced in the direct market also reflected to the listed market, where $\mathrm{P} / \mathrm{NAV}$ discounts turned into $\mathrm{P} / \mathrm{NAV}$ premiums in 2005 and market capitalisation exceeded 2 billion euro. After the start of the global financial crisis, the P/NAV has fallen back to around $50 \%$, and the market capitalisation decreased to about half of its peak levels in 2006. Thus, the P/NAV development in the Finnish market seems to be related to the development of the general market sentiment supporting the findings of e.g. Lee et al. (1991), Barkham and
Ward (1999), who have found support to the noise trader hypothesis.

As suggested by the literature, the NAV discounts of the Finnish PREOCs also vary within the sector. The three largest companies' P/NAV ratios correlate strongly with the P/NAV development in the sector, but the smaller companies - Interavanti and Suomen Säästäjien Kiinteistöt - tend to have higher than average P/NAV ratios, which react differently to property cycles. This is partly because the three larger companies dominate the calculations.

One explanation for the differences in pricing and the lack of interest of private households in investing in public real estate operating companies could be the lack of liquidity in the market. The liquidity of public vehicles is typically evaluated through market capitalisation, though yearly trading volumes or the bid-ask spreads of the companies (Bertin et al., 2005). The market values of the three largest companies are large enough to provide a liquid 
trading ground, but the two smaller companies, with market values of $€ 3$ million and $€ 43$ million, might be too small for that. In addition, in the smallest companies, the ownership is concentrated in the management, and the yearly trading volumes are very low (Table $5)$. The industry average of yearly trading is $74 \%$ when measured in number of shares and $125 \%$ when measured in market value. For the smaller companies, the liquidity remains below $10 \%$.

Table 5. Liquidity of the Finnish PREOCs

\begin{tabular}{lll}
\hline Company & $\begin{array}{l}\text { Of shares } \\
(\%)\end{array}$ & $\begin{array}{l}\text { Of market value } \\
(\%)\end{array}$ \\
\hline Citycon Plc & 68 & 119 \\
Interavanti Plc & 1 & 1 \\
Sponda Plc & 98 & 169 \\
SSK Plc & 4 & 7 \\
Technopolis Plc & 63 & 83 \\
Industry average & 74 & 125 \\
\hline
\end{tabular}

\section{PREOC PERFORMANCE ANALYSIS}

The performance of the Finnish public real estate sector is presented in this section. Historical stock price development, along with interasset correlations, are studied and discussed. In addition, the development of the OMX Helsinki Real Estate Index is compared to that of the general OMX Helsinki equity index.

Figure 4 presents the performance of the PREOCs in the studied period. Five major companies, still active and trading today, are presented: Citycon Plc, Interavanti Plc, Sponda, SSK Plc, and Technopolis Plc. These five companies where chosen to represent the general real estate market because each of them has been listed for at least 10 years and they are still being traded on the stock market. In other words, firms that have been acquired by other companies, merged, or de-listed for some other reason are not included in the performance study.

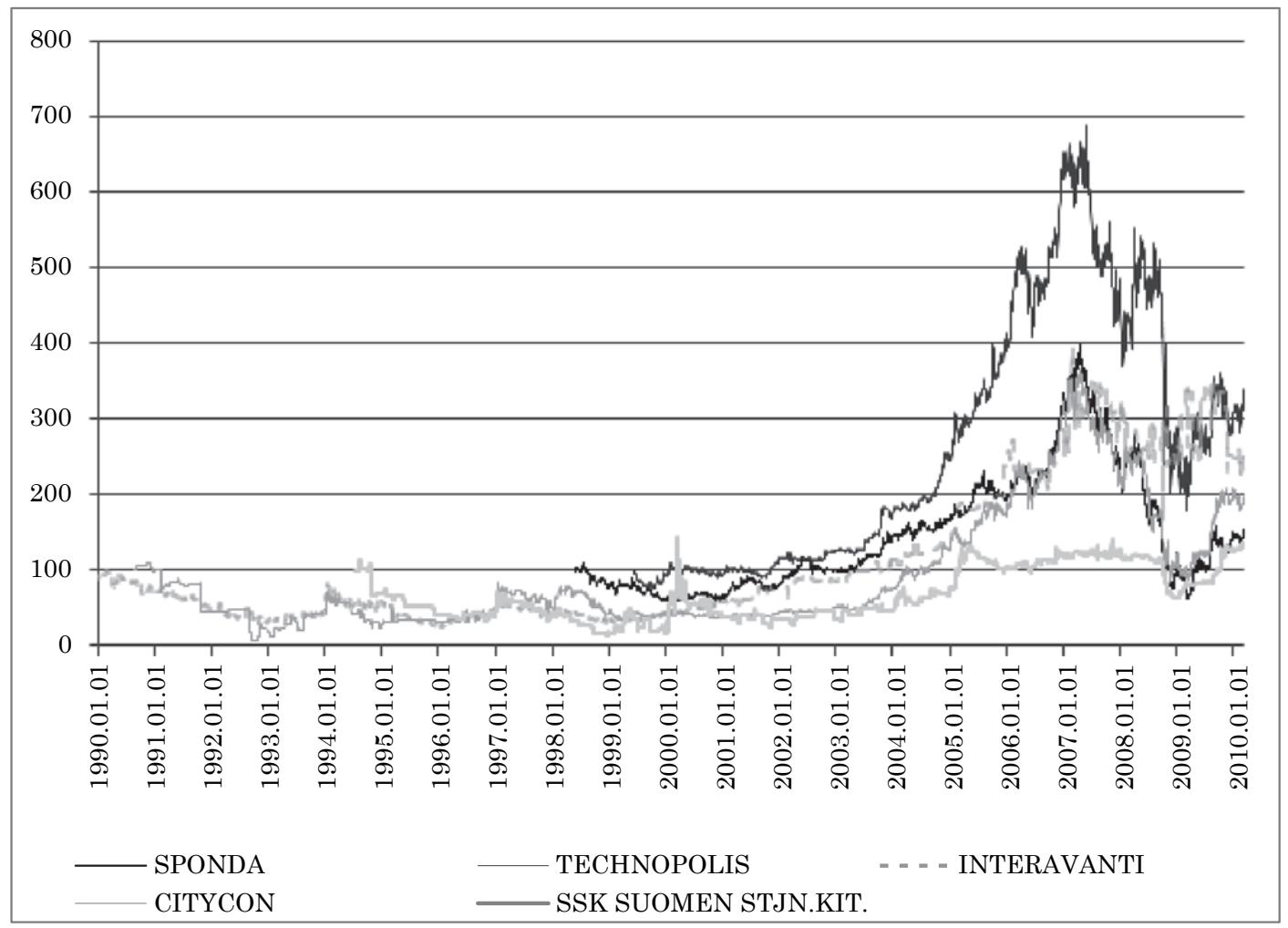

Figure 4. Historical performances of Finnish PREOCs 
Table 6. Inter-asset correlation matrix, 1990-2010

\begin{tabular}{lccccc}
\hline Company & Citycon Plc & Interavanti Plc & Sponda Plc & SSK Plc & Technopolis Plc \\
\hline Citycon Plc & 1.00 & 0.00 & 0.35 & 0.06 & 0.34 \\
Interavanti Plc & & 1.00 & 0.00 & 0.00 & -0.03 \\
Sponda Plc & & & 1.00 & -0.01 & 0.33 \\
SSK Plc & & & & 1.00 & 0.03 \\
Technopolis Plc & & & & & 1.00 \\
\hline
\end{tabular}

Figure 4 charts the historical performance of the Finnish public real estate operating companies still traded today. The three largest companies by market value in the reference group are Sponda Plc (€208M), Citycon Plc (€ 616M), and Technopolis Plc (€208M). The two significantly smaller ones, Interavanti Plc and SSK Plc, are currently valued at $€ 39 \mathrm{M}$ and at $€ 6.18 \mathrm{M}$ respectively.

The graph shows how the real estate operating companies, especially Technopolis Plc, significantly increased in value in the early 2000s. The market values peaked in April 2007, followed by a severe downturn all the way to the end of 2008 . This was for the most part explainable by the global financial recession that deterred equity markets around the world. The year 2009 was already clearly better. The PREOCs distributed an increased value of $27.4 \%$ on average. SSK Plc grew a healthy $49.1 \%$ in value, leaving the second biggest gainer, Citycon Plc, behind by $5.2 \%$ (43.9\%).

The inter-asset correlation of returns among the PREOCs is everything between 0 and 0.35 (see Table 6). Its correlation matrix shows that the correlation coefficients among the three largest and most-traded companies are between 0.33-0.35, and that the smaller, less liquid companies, do not show nearly any type of correlation to each other or the larger companies.

Table 7 lists the average annual returns and volatility for the benchmark companies. If this research had been carried out in 2007 , before the market crash, the results would have been quite different. Now, as observable, the annual returns seem rather modest. Of the studied companies, only Technopolis Plc has delivered an average annual return exceeding $10 \%$ ( $11.55 \%$, to be exact). All other equities delivered returns closer to those of fixed income securities, ranging between $1.9 \%$ and $4 \%$ per annum. Moreover, largely due to the severe downturn experienced in 2007-2008, real estate equities were quite volatile, with annualized standard deviations ranging from $33 \%$ to $81 \%$.

Table 7. Finnish PREOCs performance analysis 1990-2010

\begin{tabular}{lll}
\hline Company & $\begin{array}{l}\text { Average annual } \\
\text { return\% }\end{array}$ & $\begin{array}{l}\text { Annual volatility } \\
\text { (std. dev.)\% }\end{array}$ \\
\hline Citycon Plc & 3.33 & 66.16 \\
Interavanti Plc & 4.01 & 50.52 \\
Sponda Plc & 3.41 & 33.14 \\
SSK Plc & 1.86 & 81.03 \\
Technopolis Plc & 11.55 & 40.34 \\
\hline
\end{tabular}

As observable from Figure 5, the local stock market in Finland has been developing in quite a different manner compared to the public real estate market. Analysing the graphs makes it look like the stock market was rather stable. However, looking in more detail, we find that the stock market has historically been more volatile than that of the public real estate operating companies. The OMX Helsinki stock market's annualized volatility (standard deviation) for the study period is $31.1 \%$, while that of OMX Helsinki real estate is only $26.5 \%$. These markets exhibit a mild positive correlation (0.31) over the study period.

Next we proceed to analysing the attractiveness of Finnish PREICs from the perspective of portfolio. As known, ceteris paribus, the less the constituting assets in a multi-asset portfolio correlate with each other, the better. 


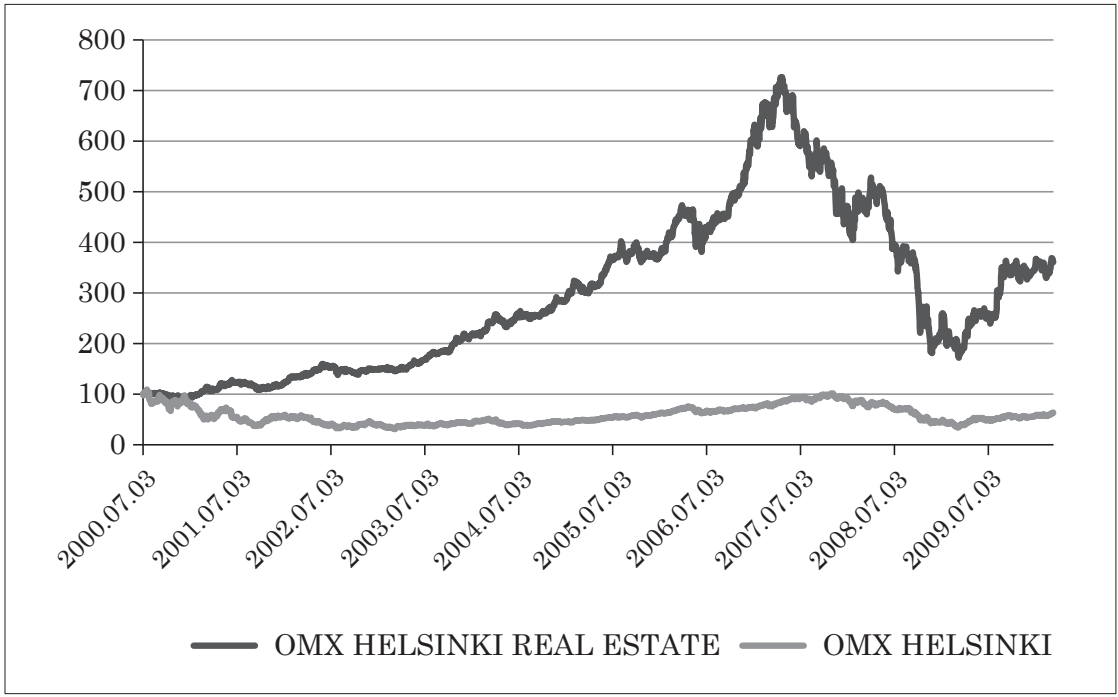

Figure 5. Volatility of PREOCs in comparison to stock market index

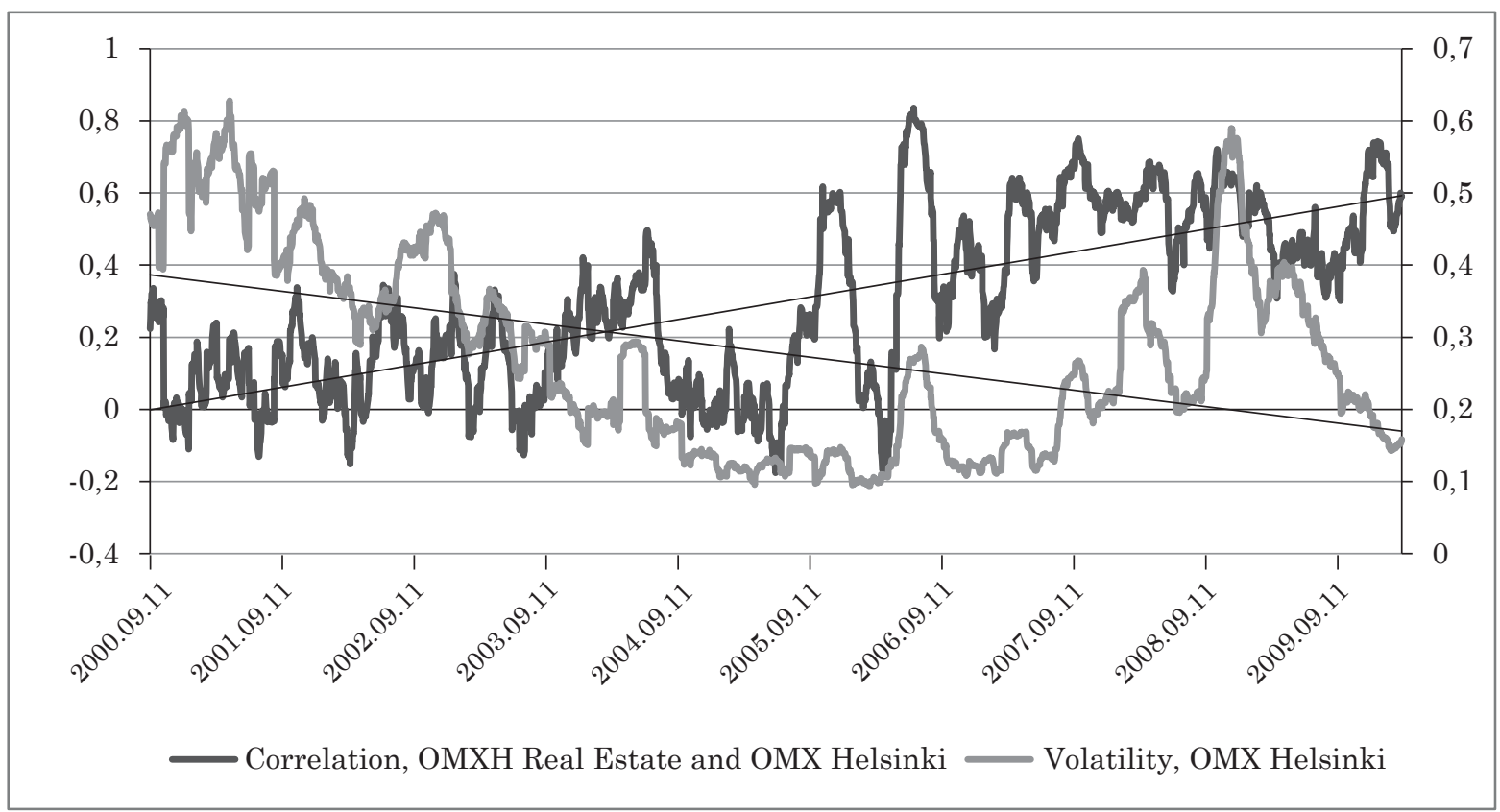

Figure 6. Rolling correlations between PREOCs and the stock market

The literature on public real estate returns and diversification benefits suggests that correlations are not stable over time (Eichholtz, 1996b; Goldstein and Nelling, 1999; Newell and Acheampong, 2001; Schindler, 2009), thus the correlations are studied as rolling correlation between the stock market and the public real estate market (see Figure 6).
The primary idea of diversification is to decrease the risk of investment portfolio. Therefore, it is of interest to study whether the observed correlation between public real estate assets and the stock market in general changes with stock market volatility. There is evidence in the earlier research both in general financial literature (see e.g. Longin and Solnik, 
1995; Ang and Bekaert, 2002) and on public real estate (see e.g. Newell and Acheampong, 2001; Liow, 2011) that the correlations between asset returns tend to increase when the market is down. To include this perspective in the analysis, another variable is included: rolling stock market volatility. Should the correlation and market market volatility have a relationship in either direction, it would have implications for asset managers trying to balance and hedge their multi-asset portfolios.

Observing the graphs we find that as stock market volatility decreases, the assets seem to exhibit higher degrees of correlation. And vice versa, as stock market volatility increases, the correlation decreases. This is an interesting finding, as contrary to the general body of literature on the topic it suggests that real estate assets constitute increasing diversification benefits during volatile times in the stock market, i.e., when the diversification benefits are most sought after.

\section{CONCLUSIONS}

The forms of real estate investment in Finnish real estate markets are still fairly limited. In terms of public equity investments in commercial real estate, Finnish legislation provides for two forms: public real estate operating companies and real estate investment trusts. Due to taxation and operational inefficiencies, no public Finn REITs have been established, and in practise, the public equity sector exists only in the form of public real estate operating companies.

The public markets for real estate equity started to develop in the 1980s when the first real estate operating companies joined the stock exchange. Thereafter, the development has correlated strongly with the development of the general economy and property markets. Today, there are five PREOCs in Finland, all focusing their investments in commercial real estate. They have property holdings of about 5 billion euro, corresponding to about $14 \%$ of the estimated size of the professionally owned commercial property market in Finland. When compared to the other mature European markets, the number of PREICs and the part they represent of the real estate market and stock market are still smaller.

As investments, PREOCs have provided fairly moderate returns, with slightly lower volatility than the OMX Helsinki stock index. The correlation with the stock market has been low, decreasing with the increasing stock market volatility, thus suggesting diversification benefits for a mixed-asset investor. Also, the inter-asset correlations in the sector have remained low, suggesting diversification possibilities also within the sector.

Despite its return and diversification characteristics, Finnish PREOCs have not been able to attract much capital from households or other investors with restricted access to direct real estate markets. The major shareholders in the sector consist of public entities, finance and insurance institutions, and companies. Foreign ownership has remained at about $10 \%$, suggesting only a moderate role for public real estate equity instruments in the internationalisation of the market.

Of interest to the real estate investor investing in the Finnish market is to see how things develop regarding the local REIT market. The REIT law, as it is known in Finland, was accepted by the parliament in 2009, but no REITs have been listed so far. Some of the reasons hindering existing real estate operating companies from setting up REITs may have to do with the rather strict requirements set by the government for qualifying as a REIT and tax neutrality. Only time will tell whether new REITs are created or whether current legislation has to be changed in order to attract investors.

\section{ACKNOWLEDGEMENTS}

The authors wish to acknowledge the Academy of Finland (project 122525) for the financial support. 


\section{REFERENCES}

Anderson, R., Conner, P. and Liang, Y. (2001) Dimensions of REIT pricing: size, growth and leverage, Prudential Real Estate Investors, Newark, NJ.

Ang, A. and Bekaert, G. (2002) International asset allocation with regime shifts, Review of Financial Studies, 15(4), pp. 1137-1187. http://dx.doi.org/10.1093/rfs/15.4.1137

Barkham, R. J. and Ward, C. W. R. (1999) Investor sentiment and noise traders: discount to net asset value in listed property companies in the U.K., Journal of Real Estate Research, 18(2), pp. 291-312.

Bertin, W. J., Michayluk, D., Prather, L. and Kofman, P. (2005) Intraday REIT Liquidity, Journal of Real Estate Research, 27(2), pp. 155-176.

Biasin, M., Giacomini, E. and Quaranta, A. G. (2010) Public REITs' governance and regulatory structure: effects on NAV discount: evidence from the Italian market, Journal of European Real Estate Research, 3(3), pp. 161-181.

http://dx.doi.org/10.1108/17539261011094704

Boudreaux, K. J. (1973) Discounts and premiums on closed-end mutual funds: a study in valuation, Journal of Finance, 28(2), pp. 515-522.

http://dx.doi.org/10.1111/j.1540-6261.1973.tb01799.x

Brounen, D. and ter Laak, M. (2005) Understanding the discount: evidence from European property shares, Journal of Real Estate Portfolio Management, 11(3), pp. 241-252.

Campbell, R. D. and Sirmans, C. F. (2002) Policy implications of structural options in the development of real estate investment trusts in Europe: lessons from the American experience, Journal of Property Investment \& Finance, 20(4), pp. 388-405.

http://dx.doi.org/10.1108/14635780210435065

Capozza, D. R. and Lee, S. (1995) Property type, size and REIT value, Journal of Real Estate Research, 10(4), pp. 363-379.

Clayton, J. and MacKinnon, G. (2001) Explaining departures from NAV in REIT pricing: noise or information?, Working paper. University of Cincinnati, Cincinnati, $\mathrm{OH}$.

Delcoure, N. and Dickens, R. (2004) REIT and REOC systematic risk sensitivity, Journal of Real Estate Research, 26(3), pp. 237-254.

Eichholtz, P. M. A. (1996a) Does international diversification work better for real estate than for stocks and bonds?, Financial Analysts Journal, 52(1), pp. 56-62. http://dx.doi.org/10.2469/faj.v52.n1.1967

Eichholtz, P. M. A. (1996b) The stability of the covariance of international property share returns, Journal of Real Estate Research, 11(2), pp. 149-158.

Eichholtz, P. M. A. (1997) Real estate securities and common stocks: a first international look, Real Estate Finance, 14(1), pp. 70-74.

EPRA (2009) Monthly market review, January 2009. European Public Real Estate Association (EPRA).
Falkenbach, H. (2009a) Diversification benefits in the Finnish commercial property market, International Journal of Strategic Property Management, 13(1), pp. 23-35. http://dx.doi.org/10.3846/1648715X.2009.13.23-35

Falkenbach, H. (2009b) Market selection for international real estate investments, International Journal of Strategic Property Management, 13(4), pp. 299-308. http://dx.doi.org/10.3846/1648-715X.2009.13.299-308

Focke, C. (2006) The development of German open-ended real estate funds, Journal of Real Estate Literature, 14(1), pp. 39-56

Fraser, W. D., Leishman, C. and Tarbert, H. (2002) The long-rum diversification attributes of commercial property, Journal of Property Investment \& Finance, 20(4), pp. 354-373. http://dx.doi. org/10.1108/14635780210435047

Goldstein, M. A. and Nelling, E. F. (1999) REIT return behavior in advancing and declining stock markets, Real Estate Finance, 15(4), pp. 68-77.

Hoesli, M. and Lekander, J. (2008) Real estate portfolio strategy and product innovation in Europe, Journal of Property Investment \& Finance, 26(2), pp. 162 176. http://dx.doi.org/10.1108/14635780810857908

Hoesli, M., Lekander, J. and Witkiewicz, W. (2004) International evidence on real estate as a portfolio diversifier, Journal of Real Estate Research, 26(2), pp. 161-206.

Hudson-Wilson, S., Fabozzi, F. J. and Gordon, J. N. (2003) Why real estate?, Journal of Portfolio Management, 29, pp. $12-25$.

Huoneistokeskus (1992) Market review, Fall 1992. Huoneistokeskus Oy., Helsinki.

Karakozova, O. (2005) Modelling and forecasting property rents and returns. Helsinki: Edita Prima Ltd. (Publications of the Swedish School of Economics and Business Administration Nr 149) ISBN 951-555-890-5 (electronic version).

KTI (2009) The Finnish property market 2009. Market review. Institute for Real Estate Economics (KTI).

Lee, C. M. C., Shleifer, A. and Thaler, R. H. (1991) Investor sentiment and the closed-end fund puzzle, Journal of Finance, 46(1), pp. 75-109.

http://dx.doi.org/10.1111/j.1540-6261.1991.tb03746.x

Ling, D. C. and Naranjo, A. (1999) The integration of commercial real estate markets and stock markets, Real Estate Economics, 27(3), pp. 483-515.

Liow, K. H. (2011) Time series behavior of average dynamic conditional correlations in European real estate securities markets: an empirical exploration, Journal of European Real Estate Research, 4(2), pp. 93-113. http://dx.doi.org/10.1108/17539261111157280

Longin, F. and Solnik, B. (1995) Is the correlation in international equity returns constant, Journal of International Money and Finance, 14(1), pp. 3-26. http:// dx.doi.org/10.1016/0261-5606(94)00001-H

Malkiel, B. G. (1977) The valuation of closed-end investmentcompany shares, Journal of Finance, 32(3), pp. 847- 
859. http://dx.doi.org/10.1111/j.1540-6261.1977. tb01993.x

McAllister, P. (1999) Globalization, integration and commercial property: evidence from the UK, Journal of Property Investment \& Finance, 17(1), pp. 8-26. http://dx.doi.org/10.1108/14635789910252774

Morri, G., McAllister, P. and Ward, C. (2005) Explaining deviations from NAV in UK property companies: rationality and sentimentality. In: 12th ERES Annual Meeting, 15-18 June, 2005, Dublin.

Mueller, G. A. and Mueller, R. G. (2009) Public and private real estate in mixed-asset portfolio, Journal of Real Estate Portfolio Management, 9(3), pp. 193-203.

NAREIT (2009) Monthly media update, January 2009. [Online] National Association of Real Estate Investment Trusts. Available at: http://www.reit.com/Portals/0/PDF/Jan09NMU.pdf

Newell, G. and Worzala, E. (1995) The role of international property in investment portfolios, Journal of Property Finance, 6(1), pp. 55-63. http://dx.doi. org/10.1108/09588689510088186

Newell, G. and Acheampong, P. (2001) The dynamics of the Australian property market risk and correlation profile, Pacific Rim Property Research Journal, 7(4), pp. 259-270.

Niskanen, J. and Falkenbach, H. (2010) REITs and correlations with other asset classes: a European perspective, Journal of Real Estate Portfolio Management, 16(3), pp. 227-239.

Oikarinen, E., Hoesli, M. and Serrano, C. (2011) The long-run dynamics between direct and securitized real estate, Journal of Real Estate Research, 33(1), pp. $73-104$.

Pagliari Jr, J. L., Scherer, K. A. and Monopoli, R. T. (2005) Public versus private real estate equities: a more refined, long-term comparison, Real Estate Economics, 33(1), pp. 147-187.

Pratt, E. J. (1966) Myths associated with closed-end investment company discounts, Financial Analyst Journal, 22(4), pp. 79-82. http://dx.doi.org/10.2469/ faj.v22.n4.79

Schindler, F. (2009) Correlation structure of real estate markets over time, Journal of Property Investment \& Finance, 27(6), pp. 579-592. http://dx.doi. org/10.1108/14635780910993177

Schulte, K.-M., Dechant, T. and Schaefers, W. (2011) Systematic risk factors in European real estate equities, Journal of European Real Estate Research, 4(3), pp. 185-224. http://dx.doi. org/10.1108/17539261111183416

Seiler, M. J., Webb, J. R. and Myer, F. C. N. (1999) Diversification issues in real estate investment, Journal of Real Estate Literature, 7(2), pp. 163-179. http://dx.doi.org/10.1023/A:1008741320860

Stevenson, S. (2000) Constraining optimal portfolios and the effect on real estate's allocation, Journal of Property Investment \& Finance, 18(4), pp. 488-506. http://dx.doi.org/10.1108/14635780010345445

Worzala, E. (1994) Overseas property investments: How are they perceived by the institutional investors?, Journal of Property Valuation \& Investment, 12(3), pp. 31-47. http://dx.doi.org/10.1108/14635789410063904 